\title{
Meningkatan Hasil Belajar Muatan Pkn Materi Pengambilan Keputusan Bersama dengan Metode Bermain Pran pada Siswa Kelas V SD Negeri Dondak Kec. Pujut Kabupaten Lombok TengahTahun Pelajaran 2019/2020
}

\author{
Baiq Sumayati \\ Guru Kelas SDN Dondak Kec. Pujut Kabupaten Lombok Tengah
}

\begin{abstract}
Abstrak. Berdasarkan hasil observasi di SD Negeri Dondak kualitas hasil belajar Pkn kelas V masih dibawah KKM, penelitian ini bertujuan untuk meningkatkan hasil belajar Pkn, melalui metode bermain peran dengan model pembelajaran cooperatif learning. Dalam penelitian ini,penulis menggunakan metode penelitian tindakan kelas. Prosedur penelitian ini berbentuk siklus yang terbagi menjadi 2 siklus. Setiap siklus terdiri dari empat tahap meliputi tahap perencanaan, pelaksanaan, pengamatan, dan refleksi. Teknik pengumpulan data menggunakan tes formatif dan observasi. Pengumpulan data ini menggunakan instrumen pengamatan observasi siswa dan kinerja guru dalam pembelajaraan, sedangkan untuk mengetahui kualitas hasil belajar siswa digunakan LKS berupa tes formatif. Hasil penelitian menunjukkan bahwa penggunaan metode bermain peran dengan model kooperatif learning dapat meningkatkan hasil belajar siswa pada mata pelajaran Pkn materi pengambilan keputusan bersama, dari nilai rata-rata prasiklus 53,88 menjadi 64,16 pada siklus I dan 78,38 pada siklus II.
\end{abstract}

Kata kunci : Bermain Peran,Koperatif Learning,Siklus,Dan Lks.

\section{PENDAHULUAN}

Pendidikan Kewarganegaraan (Citizenship) merupakan mata pelajaran yang memfokuskan pada pembentukan diri yang beragam dari segi agama, sosio-kultural, bahasa, usia dan suku bangsa untuk menjadi warga negara yang cerdas, terampil, dan berkarakter yang diamanatkan oleh Pancasila dan UUD 1945 (Kurikulum Berbasis Kompetensi, 2004). Pendidikan Kewarganegaraan mengalami perkembangan sejarah yang sangat panjang, yang dimulai dari Civic Education, Pendidikan Moral Pancasila, Pendidikan Pancasila dan Kewarganegaraan, sampai yang terakhir pada Kurikulum 2004 berubah namanya menjadi mata pelajaran Pendidikan Kewarganegaraan.

Pendidikan Kewarganegaraan dapat diartikan sebagai wahana untuk mengembangkan dan melestarikan nilai luhur dan moral yang berakar pada budaya bangsa Indonesia yang diharapkan dapat diwujudkan dalam bentuk perilaku kehidupan sehari-hari peserta didik sebagai individu, anggota masyarakat dalam kehidupan berbangsa dan bernegara.

Landasan PKn adalah Pancasila dan UUD 1945, yang berakar pada nilai-nilai agama, kebudayaan nasional Indonesia, tanggap pada tuntutan perubahan zaman, serta Undang Undang No. 20 Tahun 2003 tentang Sistem Pendidikan Nasional, Kurikulum Berbasis Kompetensi tahun 2004 serta Pedoman Khusus Pengembangan Silabus dan Penilaian Mata Pelajaran Kewarganegaraan yang diterbitkan oleh Departemen Pendidikan Nasional-Direktorat Jenderal Pendidikan Dasar Menengah-Direktorat Pendidikan Menengah Umum.

Pendidikan Kewarganegaraan ( PKn ) diberikan sejak SD sampai SLTA. Dengan PKn seseorang akan memiliki kemampuan untuk mengenal dan memahami karakter dan budaya bangsa serta menjadikan warga negara yang siap bersaing di dunia internasional tanpa meninggalkan jati diri bangsa. Melalui PKn setiap warga negara dapat mawas diri dengan perkembangan teknologi informasi dan komunikasi dewasa ini yang memberi dampak positif dan negatif. PKn juga bermanfaat untuk membekali peserta didik agar memiliki kemampuan untuk mengelola dan memanfaatkan informasi untuk bertahan hidup pada keadaan yang selalu berubah, tidak pasti dan kompetitif. 
Pada kenyataannya, PKn dianggap ilmu yang sukar dan sulit dipahami. PKn adalah pelajaran formal yang berupa sejarah masa lampau, perkembangan sosial budaya, perkembangan teknologi, tata cara hidup bersosial, serta peraturan kenegaraan. Begitu luasnya materi PKn menyebabkab anak sulit untuk diajak berfikir kritis dan kreatif dalam menyikapi masalah yang berbeda. Sementara anak usia sekolah dasar tahap berfikir mereka masih belum formal, karena mereka baru berada pada tahap Operasi Onal Konkret ( Peaget : 1920 ). Apa yang dianggap logis, jelas dan dapat dipelajari bagi orang dewasa, kadang - kadang merupakan hal yang tidak masuk akal dan membingungkan bagi siswa. Akibatnya banyak siswa yang tidak memahami konsep PKn.

Berdasarkan temuan penulis, sebagian besar siswa kurang aktif dan berfikir kritis dalam materi Negara Kesatuan Republik Indonesia (pengambilan keputusan bersama). Apabila anak menghadapi masalah kontekstual baru yang berbeda dengan yang dicontohkan, anak belum mampu berfikir kritis dan menemukan solusi dengan benar sehingga banyak anak yang menjawab salah, dan dengan alasan soalnya sulit. Karena itu wajar setiap kali diadakan tes, nilai pelajaran PKn selalu rendah dengan rata - rata kurang dari KKM.

Hal ini dapat dilihat dari hasil ulangan semester siswa kelas V SDN Dondak .Dari 23 orang siswa,hanya 10 siswa yang berhasil mendapatkan nilai sesuai standar KKM dan 13 siswa belum mencapai nilai KKM yang sudah ditetapkan yaitu 70 . Rendahnya proses dan hasil belajar siswa disebabkan oleh beberapa faktor diantaranya adalah:1)faktor siswa, Siswa masih kurang memahami konsep pengambilan keputusan bersama.Siswa masih kurang aktif dalam berdiskusi dan Siswa masih kurang terampil dalam berkomunikasi dengan teman sebaya.2)Faktor guru, Dalam menyampaikan materi guru masih menggunakan metode yang monoton dan bersifat konvensional.guru lebih banyak menggunakan metode ceramah,siswa hanya mendengarkan kemudian mencatat serta menghafal siswa masih kurang terampil dalam berkomunikasi,guru juga tidak menggunakan alat peraga,dan kurang memberikan contoh serta latihan tidak memberikan bimbingan secara menyeluruh kepada siswa

Dari analisis masalah diatas,peneliti menemukan alternatif pemecahan masalah sebagai berikut:

Guru perlu menerapkan metode pembelajaran bermain peran untuk meningkatkan keaktifan siswa dalam pembelajaran PKn tentang pengambilan keputusan bersama.

Berdasarkan hal di atas maka peneliti mengambil judul "Meningkatkan Hasil Belajar Muatan Pkn Materi pengambilan keputusan bersama Melalui Metode Bermain Peran di Kelas V SD Negeri Dondak Kecamatan Pujut Kabupaten Lombok Tengah Tahun Pelajaran 2019/2020“.

\section{LANDASAN TEORI DAN KAJIAN PUSTAKA}

PKn merupakan mata pelajaran di sekolah yang perlu menyesuaikan diri sejalan dengan kebutuhan dan tuntutan masyarakat yang sedang berubah. Hal ini merupakan fungsi PKn sebagai pembangun karakter bangsa ( nasional character building ) yang sejak proklamasi kemerdekaan RI telah mendapat prioritas, yang perlu direvitalisasi agar sesuai dengan arah dan pesan konstitusi Negara RI. Untuk itu pembentukan karakter anak yang kuat perlu penguasaan Pembelajaran Kewarganegaraan sejak dini.

Tolak ukur dalam keberhasilan pembelajaran adalah hasil belajar. Hasil belajar merupakan perubahan perilaku yang diperoleh pembelajar setelah mengalami aktivitas belajar ( Anni, 2004 : 4 ) Hasil belajar adalah perubahan perilaku yang relative menetap dalam diri seseorang sebagai akibat dari interaksi seseorang dengan lingkungannya (Hamzah:2007 : 213 ).

Berdasarkan pengertian hasil belajar di atas peneliti menyimpulkan bahwa aspek - aspek perubahan perilaku tersebut tergantung pada apa yang dipelajari oleh pembelajar. Oleh karena itu apabila pembelajar mempelajari tentang konsep, maka perubahan perilaku yang diperolah berupa penguasaan konsep. Dalam 
pembelajaran PKn pada materi pengambilan keputusan bersama . untuk mencapai hasil belajar yang memuaskan diperlukan aktivitas siswa yaitu dengan melakukan aktivitas langsung dalam melakukan keputusan bersama. Melalui aktivitas tersebut pembelajar akan lebih mengena pada siswa. Selain itu siswa juga perlu berinteraksi dengan siswa yang lain untuk membuat simpulan dengan benar.

Dalam penelitian ini hasil belajar pada pelajaran PKn materi Pengambilan keputusan bersama.Diukur melalui tes formatif dengan KKM 70, Bagi siswa yang nilainya kurang dari 70 diberi soal perbaikan dan bagi siswa yang nilainya 70 ke atas diberi soal pengayaan dalam bentuk pekerjaan rumah.

\section{Pembelajaran Kooperatif (Cooperative Learning)}

Undang-undang Sistem Pendidikan Nasional Nomor 20 tahun 2003 menyatakan bahwa pembelajaran adalah proses interaksi peserta didik dengan pendidik dan sumber belajar pada suatu lingkungan belajar. Dalam pembelajaran, guru harus memahami hakikat materi pelajaran yang diajarkannya dan memahami berbagai model pembelajaran yang dapat merangsang kemampuan siswa untuk belajar dengan perencanaan pengajaran yang matang oleh guru.

Model pembelajaran kooperatif merupakan salah satu model pembelajaran yang mendukung pembelajaran kontekstual. Sistem pembelajaran kooperatif dapat didefinisikan sebagai sistem kerja/ belajar kelompok yang terstruktur. Yang termasuk di dalam struktur ini adalah lima unsur pokok (Johnson \& Johnson, 1993), yaitu saling ketergantungan positif, tanggung jawab individual, interaksi personal, keahlian bekerja sama, dan proses kelompok.

Falsafah

mendasari pembelajaran

(pembelajaran gotong royong) dalam pendidikan adalah "homo homini socius" yang menekankan bahwa manusia adalah makhluk sosial.

$\begin{array}{ccc} & \text { Pembelajaran } & \text { kooperatif adalah } \\ \text { suatu strategi belajar mengajar yang }\end{array}$

menekankan pada sikap atau perilaku bersama dalam bekerja atau membantu di antara sesama dalam struktur kerjasama yang teratur dalam kelompok, yang terdiri dari dua orang atau lebih.

Pembelajaran kooperatif adalah salah satu bentuk pembelajaran yang berdasarkan faham konstruktivis. Pembelajaran kooperatif merupakan strategi belajar dengan sejumlah siswa sebagai anggota kelompok kecil yang tingkat kemampuannya berbeda. Dalam menyelesaikan tugas kelompoknya, setiap siswa anggota kelompok harus saling bekerja sama dan saling membantu untuk memahami materi pelajaran. Dalam pembelajaran kooperatif, belajar dikatakan belum selesai jika salah satu teman dalam kelompok belum menguasai bahan pelajaran.

Menurut Anita Lie dalam bukunya "Cooperative Learning", bahwa model pembelajaran kooperatif tidak sama dengan sekedar belajar kelompok, tetapi ada unsur-unsur dasar yang membedakannya dengan pembagian kelompok yang dilakukan asal-asalan. Roger dan David Johnson mengatakan bahwa tidak semua kerja kelompok bisa dianggap pembelajaran kooperatif, untuk itu harus diterapkan lima unsur model pembelajaran gotong royong yaitu :

1. Saling ketergantungan positif.

Keberhasilan suatu karya sangat bergantung pada usaha setiap anggotanya. Untuk menciptakan kelompok kerja yang efektif, pengajar perlu menyusun tugas sedemikian rupa sehingga setiap anggota kelompok harus menyelesaikan tugasnya sendiri agar yang lain dapat mencapai tujuan mereka.

2. Tanggung jawab perseorangan.

Jika tugas dan pola penilaian dibuat menurut prosedur model pembelajaran kooperatif, setiap siswa akan merasa bertanggung jawab untuk melakukan yang terbaik. Pengajar yang efektif dalam model pembelajaran kooperatif membuat persiapan dan menyusun tugas sedemikian rupa sehingga masing-masing anggota 
kelompok harus melaksanakan tanggung jawabnya sendiri agar tugas selanjutnya dalam kelompok bisa dilaksanakan.

3. Tatap muka.

Dalam pembelajaran kooperatif setiap kelompok harus diberikan kesempatan untuk bertatap muka dan berdiskusi. Kegiatan interaksi ini akan memberikan para pembelajar untuk membentuk sinergi yang menguntungkan semua anggota. Inti dari sinergi ini adalah menghargai perbedaan, memanfaatkan kelebihan, dan mengisi kekurangan.

4. Komunikasi antar anggota.

Unsur ini menghendaki agar para pembelajar dibekali dengan berbagai keterampilan berkomunikasi, karena keberhasilan suatu kelompok juga bergantung pada kesediaan para anggotanya untuk saling mendengarkan dan kemampuan mereka untuk mengutarakan pendapat mereka. Keterampilan berkomunikasi dalam kelompok juga merupakan proses panjang. Namun, proses ini merupakan proses yang sangat bermanfaat dan perlu ditempuh untuk memperkaya pengalaman belajar dan pembinaan perkembangan mental dan emosional para siswa.

5. Evaluasi proses kelompok.

Pengajar perlu menjadwalkan waktu khusus bagi kelompok untuk mengevaluasi proses kerja kelompok dan hasil kerja sama mereka agar

\section{Metode Bermain Peran}

Metode bermain peran adalah berperan atau memainkan peranan dalam dramatisir masalah social atau psikologis.

Bermain peran adalah salah satu bentuk permainan pendidikan yang di gunakan untuk menjelaskan perasaan, sikap, tingkah laku, dan nilai, dengan tujuan untuk menghayati perasaan, sudut pandang dan cara berfikir orang lain (Depdikbud, 1964 : 171).

Melalui metode bermain peran siswa diajak untuk belajar memecahkan masalah pribadi, dengan bantuan kelompok social yang anggotanya teman - temannya sendiri. Dengan kata lain metode ini berupaya membantu individu melalui proses kelompok sosial.
Melalui bermain peran, para siswa mencoba mengeksploitasi masalah - masalah hubungan antara manusia dengan cara memperagakannya. Hasilnya didiskusikan dalam kelas.

Proses belajar dengan menggunakan metode bermain peran diharapkan siswa mampu menghayati tokoh yang dikehendaki, keberhasilan siswa dalam menghayati peran itu akan menentukan apakah proses pemahaman, penghargaan dan identifikasi diri terhadap nilai berkembang : (Hasan, 1996 : 266 ).

\section{Penggunaan Model Bermain Peran dalam} Mata Pelajaran PKn

Menurut Sumantri (2001) bermain peran merupakan model mengajar yang berakar pada dimensi personal dan sosial dari pendidikan. Model ini mencoba membantu indivisu untuk menemukan makna pribadi dalan dunia sosial dan memecahkan dilema dilema dengan bantuan kelompok sosial. Dalam hal ini memungkinkan individu untuk bekerjasama untuk menganalisis situasi sosial terutama permasalahan interpersonal dalam mengembangkan cara - cara yang demokratis untuk menghadapi situasi tersebut.

Dalam model mengajar bermain peran, sebagian siswa adalah pemain peran yang lainnya mengamati. Seseorang meletakkan dirinya pada posisi orang lain yang juga bermain peran. Bila empati, simpati, kemarahan, dan kasih sayang serta apeksi dilakukan dalam berinteraksi, berarti bermain peran dapat dilaksanakan dengan baik / berhasil.

Hal penting dalam model mengajar bermain peran adalah keterlibatan siswa untuk berpartisipasi dalam situasi atau masalah nyata serta adanya keinginan untuk mengatasi suatu masalah bersama. Pemahaman siswa dalam model belajar bermain peran dapat memberikan contoh pada siswa dalam kehidupan sehari - hari untuk berperilaku sebagai berikut :

1. Menjajagi perasaan.

2. Menambah pengetahuan tentang sikap, nilai - nilai dan persepsinya.

3. Mengembangkan keterampilan dan sikapnya dalam memecahkan masalah. 
4. Mengkaji pelajaran dengan berbagai cara.

Langkah - Langkah Penerapan Metode Bermain Peran dalam Pembelajaran PKn.

Shaffel dalam bukunya " Role

Playing For Social Studies " menyatakan bahwa ada sembilan langkah dalam role playing yaitu sebagai berikut.

1. Membangkitkan semangat kelompok, memperkenalkan siswa dengan masalah sehingga mereka mengenalnya sebagai suatu bidang yangt harus dipelajari.

2. Pemilihan peserta, guru dan siswa menggambarkan berbagai karakter / bagaimana rupanya, bagaimana rasanya, dan apa yang mungkin mereka kemukakan. Guru dapat menentukan berbagai criteria dalam memilih siswa untuk peran tertentu.

3. Menentukan arena panggung, para pemain peran membuat garis besar scenario, tetapi tidak mempersiapkan dialog khusus.

4. Mempersiapkan pengamat, adalah sangat penting untuk melibatkan pangamat secara aktif sehingga seluruh anggota kelompok mengalami kegiatan itu dan kemudian dapat menganalisisnya. Cara guru melibatkan siswa pengamatan ilmiah dengan menugaskan mereka untuk mengevaluasi, mengomentari efektifitasnya serta urutan - urutan perilaku pemain dan mendefinisikan perasaan - perasaan serta cara - cara berfikir individu yang sedang diamati.

5. Pelaksanaan kegiatan; para pemeran mengasumsi perannya dan menghayati situasi secara sepontan dan saling merespon secara realistik.

6. Berdiskusi dan mengevaluasi; apakah masalahnya penting dan apakah peserta dan pengamat terlibat secara intelektual dan emosional.

7. Melakukan lagi permainan peran; siswa dan guru berbagi interpretasi baru tentang peran dan menentukan apakah harus dilakukan oleh individu - individu baru atau tetap oleh orang terdahulu. Dengan demikian permainan peran menjadi kegiatan konseptual yang dramatis.
8. Dilakukan lagi evaluasi dan diskusi; siswa mungkin mau menerima solusi, tetapi guru mendorong solusi yang realistik.

9. Berbagi pengalaman dan melakukan generalisasi. Tidak dapat diharapkan untuk menghasilkan generalisasi dengan segera tentang aspek hubungan kemanusiaan tentang situasi tertentu. Guru harus mencoba untuk membentuk diskusi, setelah mengalami setrategi bermain peran yang cukup lama, untuk dapat menggeneralisasi mengenai pendekatan terhadap situasi masalah serta akibat dari pendekatan itu. Semakin memadai pembentukan diskusi ini, kesimpulan yang dicapai akan semakin mendekati generalisasi

\section{METODE PENELITIAN}

Tempat,Waktu dan Subyek penelitian.

Penelitian ini bertempat di SDN

Dondak Kecamatan Pujut Kabupaten

Lombok Tengah. Tahun pelaran 2019/2020.Penelirian ini dilaksanakan mulai Juli sampai dengan September 2019. Adapun Subjek penelitian adalah siswa kelas V, dengan jumlah siswa 23 orang.

\section{Teknik Analisis Data}

Pengamatan ini dilakukan pada saat berlangsungnya pelaksanaan perbaikan pembelajaran di SD Negeri Dondak .Adapun data - data yang diperoleh adalah sebagai berikut.

\section{Hasil Data Kualitatif}

Dalam kegiatan pengumpulan data secara kualitatif, pengamat menggunakan lembar observasi guru. Pengamat memberikan tanda cek $(\sqrt{ })$ pada kolom kemunculan sesuai indikator tersebut.

Pengamatan yang dilakukan oleh pengamat ( observer ) adalah tentang keefektifan metode bermain peran dalam meningkatkan motivasi siswa dalam pembelajaran PKn khususnya tentang materi Pengambilan keputusan bersama. Untuk mendapatkan data yang lebih tepat, maka fokus pengamatan ditekankan pada :

a. Kegiatan guru dalam menerapkan model pembelajaran cooperative learning siswa 


\section{b. Aktifitas anak dalam pelaksanaan pembelajaran \\ c. Keaktifan siswa dalam pelaksanaan bermain peran \\ d. Indikator yang diamati pada lembar observasi guru terlampir.}

\section{Hasil Data Kuantitatif}

Data kuantitatif diperoleh dari hasil nilai tes formatif. Dari hasil tersebut dapat untuk mengukur tingkat keberhasilan pembelajaran. Dari hasil nilai tes formatif tersebut dapat diketahui tingkat keberhasilan penggunaan model pembelajaran cooperative learning siswa dalam meningkatkan motivasi siswa. Data kuantitatif tersebut dibuat sesuai dengan pedoman penilaian yang telah dibuat oleh guru. Setelah guru memberikan penilaian lalu menganalisis perbutir soal. Hasil analisis siswa terlampir.

\section{HASIL PENELITIAN DAN PEMBAHASAN}

Pelaksanaan pembelajaran diawali dengan melakukan pembelajaran awal (pra siklus) dengan melalui tahap perencanaan, pelaksanaan, pengamatan, dan refleksi. Selanjutnya dilakukan perbaikan pembelajaran pada siklus I dan siklus II dengan melalui tahap yang sama dengan pra siklus.

Penelitian yang dilakukan pada siswa kelas V SD Negeri Dondak Kecamatan Pujut Kabupaten Lombok Tengah terkait hasil belajar PKn tentang Pengambilan keputusan bersama. melalui metode bermain peran dengan model pembelajaran cooperative learning, yang dilaksanakan dalam perbaikan pembelajaran pada siklus I dan siklus II secara lengkap dijabarkan sebagai berikut.

\section{Hasil Data Awal}

Dari hasil kegiatan observasi sebelum pelaksanaan penelitian, diperoleh hasil observasi awal dari 23 orang siswa, 10 orang siswa yang belum tuntas pembelajarannya atau diperoleh 43,47 \%, sementara yang telah tuntas hasil belajar sebanyak 13 orang siswa dan dinyatakan tuntas atau sebesar 56,52 \%. Hasil tersebut menjadi alasan peneliti untuk melakukan penelitian tindakan kelas (PTK), akan tetapi dalam proses penelitian ini yang menjadi subyek adalah kelulusan siswa kelas V SD Negeri Dondak Kecamatan Pujut Kabupaten Lombok Tengah.

\section{Tindakan Siklus I}

a. Observasi Aktivitas Siswa

Berdasarkan hasil observasi aktivitas siswa dalam kegiatan belajar mengajar diperoleh jumlah rata-rata prosentase $55,33 \%$ berdasarkan criteria yang telah ditetapkan menunjukan bahwa aktivitas belajar siswa berada pada kategori cukup.

b. Observasi Aktivitas Guru

Berdasarkan hasil tabel 3 menunjukkan aktivitas guru dalam kegiatan belajar mengajar berada pada prosentase $56,5 \%$ atau berada pada kriteria Kurang sehingga perlu tindak lanjut pada siklus selanjutnya.

c. Tes Individu

Dari data hasil belajar peserta didik pada siklus I diatas diperoleh jumlah sebesar 1.155 dengan rata-rata prestasi belajar peserta didik 64,16 dengan jumlah peserta didik yang tuntas 10 orang atau $43,47 \%$ dan peserta didik yang tidak tuntas 13 orang atau 56,52\%. Dari hasil pelaksanaan tindakan siklus I, maka dapat disimpulkan bahwa pelaksanaan tindakan belum sepenuhnya berjalan dengan baik. Oleh karena itu, peneliti lebih memperhatikan kembali hal-hal apa saja yang belum terlaksana dengan baik serta memperhatikan kembali faktor-faktor apa saja yang menjadi penyebab utama pada siswa dalam meningkatkan hasil belajar mereka.

Adapun keberhasilan dan kegagalan yang terjadi pada siklus 1 adalah sebagai berikut:

a. Guru belum terbiasa menciptakan suasana pembelajaran yang mengarah kepada pendekatan pembelajaran kooperatif dengan metode bermain peran. Hal ini diperoleh dari hasil observasi terhadap aktifitas guru dalam proses belajar mengajar hanya mencapai $56,5 \%$.

b. Sebagian siswa belum terbiasa dengan kondisi belajar menggunakan pendekatan pembelajaran kooperatif metode bermain peran. Mereka merasa senang dan antusias dalam belajar. Hal ini bias diliat dari hasil observasi terhadap aktivitas siswa dalam 
poses belajar mengajar hanya mencapai $55,33 \%$

c. Hasil belajar siswa pada siklus 1 mencapai rata-rata 64,16

d. Masih ada kelompok yang belum bisa menyelesaikan tugas dengan waktu yang ditentukan. Hal ini karena anggota kelompok tersebut kurang serius dalam belajar.

e. Masih ada kelompok yang kurang mampu dalam mempresentasikan kegiatan. Untuk memperbaiki kelemahan dan mempertahankan keberhasilan yang telah dicapai pada siklus 1, maka pada pelaksanaan siklus II dapat dibuat perencanaan sebagai berikut :

$>$ Memberikan motivasi kelompok agar lebih aktif lagi dalam pembelajaran

$>$ Lebih intensip membimbing kelompok yang mengalami kesulitan

$>$ Memberi pengakuan atau penghargaan.

\section{Tindakan Siklus II}

a. Aktivitas Siswa

Berdasarkan hasil observasi menunjukkan aktivitas siswa dalam kegiatan belajar mengajar diperoleh jumlah rata-rata persentase 86,5\% berdasarkan criteria yang telah ditetapkan menunjukan bahwa aktivitas belajar siswa berada pada kategori Baik atau terjadi peningkatan dari siklus I ke siklus II sebesar 29,17\%.

b. Aktivitas Guru

Berdasarkan hasil observasi aktivitas guru dalam kegiatan belajar mengajar berada pada prosentase $81 \%$ atau berada pada kriteria Baik sesuai dengan criteria yang telah ditetapkan dalam penelitian ini. Berdasarkan pengamatan aktivitas guru pada siklus II ternyata aktivitas guru dalam kegiatan belajar mengajar telah terlaksana dengan baik bahkan terjadi peningkatan yang signifikan dari siklus I ke siklus II sebesar 21,5\%.

c. Tes Individu

Dari data prestasi belajar peserta didik pada siklus I diatas diperoleh jumlah sebesar 1.375 dengan rata-rata prestasi belajar peserta didik 78,38 dengan jumlah peserta didik yang tuntas 20 orang atau $86,69 \%$ dan peserta didik yang tidak tuntas 3 orang atau 13,04\%. Dengan demikian kemampuan hasil belajar siswa telah menunjukan peningkatan yang signifikan dimana terjadi kenaikan sebesar 27,78 \% dari siklus I sebesar 55,55 \% ke Siklus II sebesar $83,33 \%$.

\section{PEMBAHASAN}

Berdasarkan hasil penelitian yang telah dilakukan, memberikan informasi bahwa penerapan metode kooperatif tipe bermain peran merupakan alternatif untuk meningkatkan hasil belajar siswa. Hal tersebut dapat dibuktikan dengan peningkatan kemampuan hasil belajar siswa dalam menyelesaikan soal sesuai dengan hasil penelitian yang telah dilakukan dapat dijelasakan sebagai berikut : secara keseluruhan data hasil analisis observasi terhadap aktivitas siswa dan guru, serta tes untuk mengetahui hasil belajar siswa dalam memahami dan menguasai materi yang dijadikan dalam proses pembelajaran dengan menyelesaikan soal yang ditugaskan tampak terjadi peningkatan setelah pemberian tes awal dan hal ini dapat dilihat pada perolehan skor siswa pada setiap siklus antar sebelum dan sesudah tindakan baik pada siklus I maupun siklus II.

Adapun bentuk motivasi yang diberikan peneliti/guru adalah melalui permainan teka teki silang (TTS) dengan membagi siswa menjadi 2 (dua) kelompok dan berlomba untuk memenangkan pertandingan dimana pemenang mendapatkan hadiah dan yang kalah mendapatkan hukuman sesuai dengan peraturan yang telah disepakati bersama antara guru dan siswa. Metode ini meningkatkan keaktifan siswa dalam hal:

$>$ Siswa pada waktu menerima pelajaran memperhatikan penjelasan yang diberikan oleh guru dengan baik.

$>$ Berpartisipasi dalam kegiatan pembelajaran, sudah ada keinginan untuk mencari penelesaian soal dari guru.

$>$ Mau bertanya jika ada kesulitan, dan mulai berani untuk mengerjakan didepan walaupun belum bisa. 
Meskipun pada siklus I persentase dan kriteria yang diperoleh hasil analisis aktivitas belum mencapai indikator yang ditetapkan, namun pada siklus II menunjukkan peningkatan yang signifikan dan dapat dikatakan aktivitas siswa mengikuti pembelajaran, rata-rata dalam kategori sangat baik dan sudah mencapai indikator kinerja. Adapun kekurangan pada siklus I adalah masih kurangnya motivasi dari guru dalam pembelajaran serta masih banyak siswa yang belum memahami materi yang disampaikan guru sehingga mengurangi hasil belajar serta siswa masih cenderung mengharapkan jawaban dari temannya. Hal ini juga dapat dilihat pada analisis tes kemampuan siswa, dimana pada siklus I hanya 10 dari 18 siswa yang tuntas dan masih terdapat 8 orang siswa yang masih memperoleh nilai dibawah standar ketuntasan individu serta ketuntasan klasikal belum mencapai indikator keberhasilan. Untuk mengatasi masalah tersebut, maka rekomendasi yang dilakukan peneliti adalah membimbing siswa dan lebih mengoptimalkan motivasi kepada siswa tentang cara menyelesaikan tugas dengan benar dan meminta siswa untuk lebih memperhatikan penjelasan guru sehingga nilai perolehan siswa meningkat pada siklus II.

Berdasarkan pelaksanaan tindakan siklus I, diperoleh daya serap klasikal sebesar 64,16 dan ketuntasan belajar klasikal yang dicapai pada tes kemampuan pada siklus I didapatkan sebesar 55,55\% atau tedapat 10 siswa yang tuntas dari 23 orang siswa. Persentase ketuntasan klasikal pada siklus I ini menunjukkan belum mencapai indikator keberhasilan belajar pada umumnya yaitu $70 \%$. Nilai rata-rata perolehan sebesar 65 , sehingga dilanjutkan penelitian pada tahap selanjutnya (siklus II) yang akhirnya memperoleh nilai yang memuaskan.

Hasil yang diperoleh pada siklus II lebih baik daripada hasil siklus I. Dalam hal ini, adanya peningkatan ini terjadi karena kekurangan-kekurangan yang terdapat pada siklus I dapat diminimalisir. Dengan demikian terjadi peningkatan hasil yang signifikan, dimana ketuntasan belajar klasikal mencapai
$83,33 \%$, atau hanya ada 20 siswa dari 23 siswa yang dinyatakan tuntas dengan perolehan nilai rata-rata 78,38. Perolehan daya serap klasikal sebesar 78,38\%. Dari hasil perolehan tindakan siklus II tersebut dapat diketahui bahwa nilai perolehan sudah mencapai standar ketuntasan belajar. Perolehan nilai secara individu juga sudah memenuhi kriteria ketuntasan belajar mengajar yang tetapkan disekolah. Penerapan metode kooperatif tipe Bermain Peran dalam pembelajaran PKn sangat membantu meningkatkan pemahaman belajar siswa sehingga dalam menyelesaikan soal serta meningkatkan hasil belajar siswa dalam belajar.

\section{PENUTUP}

Berdasarkan hasil penelitian, maka kesimpulan yang dapat ditarik dari penelitian ini, yaitu penggunaan model pembelajaran kooperatif tipe Bermain peran dapat meningkatkan hasil belajar siswa pada pembelajaran PKn di Kelas V SD Negeri Dondak , Kecamatan Pujut Kabupaten Lombok Tengah. Pada pelaksanaan siklus I, didapatkan ketuntasan belajar klasikal sebesar $55,55 \%$ dan daya serap klasikal sebesar $55,33 \%$ serta persentase nilai rata-rata 64.16. Pada siklus II, ketuntasan belajar klasikal sebesar 83,33 \% serta daya serap kalsikal sebesar $86,5 \%$ serta persentase nilai rata-rata $78,38 \%$. Pembelajaran dengan melalui model pembelajaran kooperatif tipe Bermain peran merupakan salah satu strategi yang perlu dikembangkan oleh setiap guru dalam proses belajar mengajar dikelas dengan harapan dapat meningkatkan kemampuan akademik, meningkatkan kreativitas siswa untuk belajar dari berbagai sumber serta meningkatkan motivasi belajar siswa.

Saran

Dari hasil penelitian yang dilakukan,
maka ada beberapa sarankan agar pembelajaran menggunakan model pembelajaran kooperatif tipe Bermain Peran dapat diterapkan di SD Negeri Dondak , Kecamatan Pujut , Kabupaten Lombok Tengah. Bagi calon guru maupun guru-guru tetap agar bisa mengembangkan kreatifitas mengajar dalam menerapakan model-model 
pembelajaran yang baru di sekolah pada mata pelajaran yang diajarkan, yang juga membuat siswa juga merasa menyenangkan.

\section{DAFTAR PUSTAKA}

Andayani, dkk. 2010, Pemantapan Kemampuan Profesional. Jakarta, Universitas Terbuka.

Aswani, Zaenul,2004, Tes dan Asesmen di $S D$, Jakarta, Universitas Terbuka.

Denny, Setyawan, 2005, Komputer dan Media Pembelajaran, Jakarta, Universitas Terbuka.

Gatot, Muhsetyo, Drs. M.Sc, dkk, 2007, Pembelajaran PKN, Jakarta, Universitas Terbuka.

Mulyani Sumantri, Nana Syaodih. 2007. Perkembangan Peserta Didik. Jakarta, Universitas Terbuka.

Samsudin, Abin, 2004, Profesi Keguruan 2, Jakarta, Universitas Terbuka.

Suciati, Drs. Dkk, 2004, Belajar dan Pembelajaran 2, Jakarta, universitas Terbuka.

Wardani, I.G.A.K, 2008, Penelitian Tindakan Kelas, Jakarta, Universitas Terbuka.

Wahyudi Duin, Supaiyati, Ishak, Abduhak, 2001, Pengantar Pendidikan, Jakarta, Universitas Terbuka.

Dra. Dyah Sriwilujeng, M.Pd, Buku PKn untuk SD Kelas V, Jakarta, Esis.

Pranaja S dkk, Buku Fokus PKn untuk SD Kelas V, Jakarta, Sindutama. 